\title{
Overweight and obesity vs. simple carbohydrates consumption by elderly people suffering from diseases of the cardiovascular system
}

\author{
Agata Skop-Lewandowska', Joanna Zając', Emilia Kolarzyk ${ }^{1}$ \\ ${ }^{1}$ Department of Hygiene and Dietetics, MedicalCollege, Jagiellonian University, Krakow, Poland \\ Skop-Lewandowska A, Zając J, Kolarzyk E. Overweight and obesity vs. simple carbohydrates consumption by elderly people suffering from \\ diseases of the cardiovascular system. Ann Agric Environ Med. 2017; 24(4): 575-580. doi: 10.5604/12321966.1233555
}

\begin{abstract}
Introduction. Overweight and obesity belong to the alarming and constantly increasing problems of the $21^{\text {st }}$ century among all age groups. One of the major factors enhancing these problems are simple carbohydrates commonly found in popular sweet drinks.

Objective. The aim of the study was to estimate the nutritional patterns of elderly people with diagnosed cardiovascular system diseases, and analysis of the relationship between consumption of simple carbohydrates and prevalence of overweight and obesity.

Materials and Method. From 233 individuals hospitalized in the Clinic of Cardiology and Hypertension in Krakow, Poland, a group of 128 elderly people was selected ( 66 women and 62 men). Actual food consumption for each individual was assessed using a 24-hour nutrition recall. BMI values was calculated for assessment of nutritional status. Statistical analysis was performed on two groups: one with $\mathrm{BMI}<25 \mathrm{~kg} / \mathrm{m}^{2}$ and other with $\mathrm{BMI} \geq 25 \mathrm{~kg} / \mathrm{m}^{2}$.

Results. Overweight was stated among $33.8 \%$ of women and $50 \%$ of men, obesity among $27.7 \%$ of women and $17.7 \%$ of men. Results indicated that consumption of products rich in sucrose was associated with overweight and obesity. People with overweight and obesity statistically more often ate sweet products comparing to those with proper weight: $46.2 \mathrm{~g}$ vs $33.8 \mathrm{~g}$. The growing world-wide epidemic of overweight and obesity is one of the main priorities of preventive medicine remains changing eating patterns As observed in this study, one additional spoon of sugar consumed daily increases the risk of being overweight or obese by about $14 \%$.

Conclusion. Overweight and obesity was found among $60 \%$ of the examined elderly people. Correlation was found between rise in risk of obesity or overweight by about $14 \%$ with each additional spoon of sugar $(5 \mathrm{~g})$ eaten every day.
\end{abstract}

\section{Key words}

sucrose, added sugars, overweight and obesity, food intake, elderly

\section{INTRODUCTION}

In recent years, an increased number of overweight and obese people has been observed in developing countries. Obesity is classified as an epidemic disease by WHO experts and the National Institute of Health [1]. Obesity is a world-wide problem and affects all age and socio-economic groups. WHO experts estimate that the number of obese people in the world will increase from $256 \mathrm{mln}$ in 1996 to $600 \mathrm{mln}$ in 2030 [2]. The data obtained from representative national studies of the adult population in Poland conducted within the WOBASZ study (2003-2005) show a high prevalence of overweight or obesity $\left(\mathrm{BMI} \geq 25 \mathrm{~kg} / \mathrm{m}^{2}\right): 61.6 \%$ of men and $50.3 \%$ of women [3]. In Natpol Plus examination (2000) the frequency of overweight was estimated as $39-41 \%$ among the male group and $28-29 \%$ in the female group, while obesity was assessed as $16-21 \%$ of men and $19-22 \%$ of women [4].

The relationship between overweight and obesity and general mortality and mortality caused by diet-dependent

Address for correspondence: Agata Skop-Lewandowska, Department of Hygiene and Dietetics, MedicalCollege, Jagiellonian University, Kopernika 7, 31-034 Krakow, Poland

Tel.: +48 124223720

E-mail: agataskop@interia.pl

Received: 18 August 2014; accepted: 14 November 2014; first published on February 2017 diseases has been described in epidemiological studies, and cardiovascular system diseases are in the first position in the WOBASZ study $[3,5,6]$. It cannot be forgotten that among elderly people there are interactions between pathophysiological mechanisms of diseases and changes connected with growing old. In old age, the energy needs are lower because of slower anabolic processes in the organism, and increased catabolism of proteins. Slower peristalsis, smaller production of gastric acids and lower intestine absorption are usually observed. From the physiological aspect, these changes result in worse utilization of nutritional components by cells and tissues. These natural effects of growing older, together with nutritional mistakes, favour the development of overweight and obesity. This is why people with cardiovascular problems require specialized dietetic treatment. Literature data indicate that among the many nutritional components a proper supply of simple carbohydrates and fats in the diet plays an important role in secondary prevention of overweight and obesity $[7,8]$.

\section{OBJECTIVE}

The aim of the study was to estimate the nutritional patterns of elderly people with diagnosed cardiovascular system diseases 
from the aspect of realization of dietetic nutrition rules, and investigating whether there is a relationship between consumption of simple carbohydrates, also taking under consideration fats and prevalence of overweight and obesity.

\section{MATERIALS AND METHOD}

Among 233 persons hospitalized in the Clinic of Cardiology and Hypertension (UJCM) in Krakow, Poland, (with confirmed diagnosis of cardiovascular system diseases lasting longer than 1 year) a group of older people was selected (60 years and more). This group consisted of 128 individuals (66 women and $62 \mathrm{men}$ ), average age: $73.2 \pm 6.9$ years. All subjects gave written consent prior to their recruitment to the study and the study received the approval of the Ethics Committee for Human Research of the Jagiellonian University Medical College in Krakow.

For every studied person the basic measurements were taken: body weight and height and Body Mass Index (BMI) were calculated. The following ranges of BMI were specified: $<18.5 \mathrm{~kg} / \mathrm{m}^{2}$ - underweight; $18.5-24.9 \mathrm{~kg} / \mathrm{m}^{2}-$ proper weight; $25.0-29.9 \mathrm{~kg} / \mathrm{m}^{2}$-overweight; > $30.0 \mathrm{~kg} / \mathrm{m}^{2}$ - obesity. Prevalence of abdominal obesity was based on waist circumference $\geq 88 \mathrm{~cm}$ in the female group and $\geq 102 \mathrm{~cm}$ in the male group.

Actual food consumption of each of the respondents was assessed using a 24-hour nutritional recall. Recalls covered 2 non-consecutive weekdays and one Sunday. Recalls were carried out with a help of the Album of Food Products and Dishes (Warsaw 2000), with 201 colour photographs of various food products and dishes [9]. The album helped to assess the kinds and sizes of portions of food items and meals. Recalls were the basis for assessing quantitative content, composition and nutritional value of an average daily nutrition ration (DNR). The mean energy value and levels of basic food components and their share in DNR were calculated with the use of computer programme DietaPro. The results, calculated individually for each person, were compared with the nutritional norms published by the Institute of Food and Nutrition in Warsaw [10], the recommendations of Polish Forum of Prophylactics of Cardiovascular Diseases [11], Healthy Diet according to Polish Cardiology 2012 [12], and recommendations of the European Food Safety Authority (EFSA) [13].

The consumption frequency of 39 food products during the month preceding the examination was estimated with the use of the Food Frequency Questionnaire - FFQ This questionnaire was validated and recommended by the National Food and Nutrition Institute in Warsaw. The examined food products were classified into 12 groups. The consumption frequency of nutritional products was estimated on the basis of 7 categories (ranks):

1 - 'I do not eat at all';

2 - 'I eat once a month';

3 - 'I eat 2-3 times a month';

4 - 'I eat once a week';

5 - 'I eat 2-3 times a week';

6 - 'I eat 4-6 times a week';

7 - 'I eat every day'.

For a proper interpretation of the average ranges of consumption frequency for each product the following ranges were used:
$1-1.49$ - not consumed at all;

1.5-2.49 - consumed once a month;

2.5-3.49 - consumed 2-3 times a month;

3.5-4.49 - consumed once a month;

4.5-5.49 - consumed 2-3 times a week;

5.5-6.49 - consumed 4-6 times a week;

$6.5-7$ - every day.

Statistical analysis. Analysis of the group of obese or overweight respondents was compared with people with $\mathrm{BMI} \leq 25$, according to nutrient intake and consumption frequency of different groups of products (ranks 1-7). Firstly, the groups were described (mean \pm standard deviation) and compared by one-way Anova in the case of nutrients supply, and Mann-Whitney test in the case of product consumption frequency.

Relative risks (odds ratios) of having overweight or obesity due to daily sucrose, lactose and starch consumption were assessed using uni- and multivariate logistic models. The results were adjusted to fats and other hydrocarbons, as well as gender. The nutritional sucrose-rich products were also examined as a potential risk factor of gaining weight, as well as products rich in fats. In this case, only products which appeared to be significant in univariate logistic regression were taken into consideration in the final models. Results were also adjusted for gender. All final models were checked for collinearity between independent variables. The statistical software package Stata/IC 12.0 for Windows, Stata Corp LP was used. A 'p' value below 0.05 was considered as statistically significant.

\section{RESULTS}

It was found that the energy value of analyzed DNR was too low (for age, gender, body mass and low level of physical activity) and covered $70 \%$ of the recommended value. In the total energy value, the participation of carbohydrates and fats was in accordance with nutritional recommendations, but the participation of proteins in general energy value of the diet slightly exceeded recommendations (males - $16 \%$ of energy; females $-15.5 \%$ of energy) (Tab. 1 ).

The consumption of fats and fatty acids in DNR was statistically more significant among men than women. The consumption of Saturated Fatty Acids (SFA) was on the level of $10.6 \%$ DNR among both genders. These values were higher than the nutritional recommendations, according to which SFA should constitute not more than $10 \%$ of the overall energy intake, and for people with increased risk of cardiovascular system diseases this should be even lower: below $7 \%$ of the total energy intake $[10,11,12]$.

The consumption of monounsaturated fatty acids (MUFA) was in accordance with nutritional recommendations and delivered $12.6 \%$ of energetic value of DNR in men and $11.7 \%$ of women. The share of polyunsaturated fatty acids (PUFA) in respondents' diet was insufficient in both groups $(4.6 \%$ energy of DFR in men and $4.1 \%$ energy of DFR in women group) versus nutritional recommendations. Linoleic acid (omega-6) delivered $3.37 \%$ of DFR energy value in men and $3.04 \%$ in women. These values were insufficient when taking into consideration the latest nutritional recommendations of the European Food Safety Authority (EFSA) [13], according to which a well-balanced diet should supply $4 \%$ of energy 
from linoleic acid (LA) and $0.5 \%$ of energy from alfa-linoleic acid (ALA.) The share of alfa-linoleic acid exceeded recommendations and delivered nearly $1 \%$ of DFR energy value among the examined men and women(Tab. 1).

Table 1. The percentage share of proteins, carbohydrates and fats in energetic value of DNR of examined persons

\begin{tabular}{|c|c|c|c|c|c|c|}
\hline \multirow[b]{2}{*}{ Ingredient } & \multicolumn{3}{|c|}{ Men } & \multicolumn{3}{|c|}{ Women } \\
\hline & [kcal] & $\begin{array}{l}\text { Recom- } \\
\text { mended } \\
\text { intake }\end{array}$ & [\%] & [kcal] & $\begin{array}{l}\text { Recom- } \\
\text { mended } \\
\text { intake }\end{array}$ & [\%] \\
\hline Energy value & 1471.54 & 2100 kcal* $^{*}$ & - & 1346.8 & 1900 kcal* $^{*}$ & - \\
\hline Carbohydrates & 783.6 & $50-75 \% *$ & 53.3 & 742.76 & $50-75 \% *$ & 55.13 \\
\hline Sucrose & 150.28 & $<10 \% *$ & 10.21 & 142.0 & $<10 \% *$ & 10.54 \\
\hline Protein & 235.96 & $10-15 \% *$ & 16.0 & 208.8 & $10-15 \% *$ & 15.53 \\
\hline Fat & 451.98 & $<30 \% * * *$ & 30.7 & 395.28 & $<30 \% * * *$ & 29.34 \\
\hline Saturated fatty acids & 156.51 & $\begin{array}{l}<10 \% * * \\
<7 \% * * *\end{array}$ & 10.6 & 142.92 & $\begin{array}{l}<10 \% * * \\
<7 \% * * *\end{array}$ & 10.6 \\
\hline $\begin{array}{l}\text { Monounsaturated } \\
\text { fatty acids }\end{array}$ & 184.95 & $<20 \% * * *$ & 12.6 & 157.86 & $<20 \% * * *$ & 11.7 \\
\hline $\begin{array}{l}\text { Polyunsaturated fatty } \\
\text { acids }\end{array}$ & 68.31 & $6-10 \% * * *$ & 4.6 & 56.1 & $6-10 \% * * *$ & $\begin{array}{c}4.1 \\
3.04\end{array}$ \\
\hline Linoleic acid, n-6 & 49.68 & $4 \%$ **** & 3.37 & 41.04 & $4 \% * * * *$ & 0.92 \\
\hline Alfa-linoleic acid, n-3 & 14.67 & $0.5 \% * * * *$ & 0.99 & 12.51 & $0.5 \% * * * *$ & 0.92 \\
\hline
\end{tabular}

$\mathrm{BMI}<25 \mathrm{~kg} / \mathrm{m}^{2}$ was stated in the case of $32.3 \%$ of men and in $38.5 \%$ of women. Overweight was observed in $50 \%$ of men and in $33.8 \%$ of women, and obesity in $17.7 \%$ of men and in $27.7 \%$ of women (Tab. 2). For all obese women and men, abdominal obesity determined on the basis of waiste circumference ( $\geq 102 \mathrm{~cm}$ in men and $\geq 88 \mathrm{~cm}$ in women) was stated.

Table 2. Distribution of BMI value in examined population

\begin{tabular}{lcccc}
\hline BMl categories & $\begin{array}{c}\text { Total } \\
{[\%]}\end{array}$ & $\begin{array}{c}\text { Men } \\
{[\%]}\end{array}$ & $\begin{array}{c}\text { Women } \\
{[\%]}\end{array}$ & $\mathrm{p}$ \\
\hline$<18.5 \mathrm{~kg} / \mathrm{m}^{2}$ & - & - & - & \\
\hline $18.5-24.9 \mathrm{~kg} / \mathrm{m}^{2}$ & 35.4 & 32.3 & 38.5 & \multirow{2}{*}{0.157} \\
\hline $25-29.9 \mathrm{~kg} / \mathrm{m}^{2}$ & 41.7 & 50.0 & 33.8 & \\
\hline$\geq 30 \mathrm{~kg} / \mathrm{m}^{2}$ & 22.8 & 17.7 & 27.7 &
\end{tabular}

In the next step of this study, the percentage share of chosen energy components in the energy value of DNR and BMI categories were compared. The respondents were divided into 2 groups: I - normal weight individuals (BMI $<25 \mathrm{~kg} / \mathrm{m}^{2}$ ), and II - overweight/obese respondents (BMI $\geq$ $\left.25 \mathrm{~kg} / \mathrm{m}^{2}\right)$ (Tab. 3).

In general, there were no statistically significant differences between the energy value of diets and chosen energy substrates. The exception was the consumption of sucrose and starch among respondents with $\mathrm{BMI}<25 \mathrm{~kg} / \mathrm{m}^{2}$ and $\mathrm{BMI}>25 \mathrm{~kg} /$ $\mathrm{m}^{2}$. Sucrose consumption in the examined population with overweight and obesity significantly exceeded nutritional recommendations, and was on the level of $13.7 \%$ of the energy value of DNR, but in those with $\mathrm{BMI}<25 \mathrm{~kg} / \mathrm{m}^{2}$ this was $9.7 \%$, close to the upper limit.
Table 3. Characteristics of macronutrients in group with proper BMI and high $\mathrm{BM}$

\begin{tabular}{lcccc}
\hline & Total & $\begin{array}{c}\mathrm{BMl}<25 \\
\mathrm{~kg} / \mathrm{m}^{2}\end{array}$ & $\begin{array}{c}\mathrm{BMl} \geq 25 \\
\mathrm{~kg} / \mathrm{m}^{2}\end{array}$ & $\mathrm{p}$ \\
\hline Energy [kcal] & $1367.8 \pm 535.87$ & $1397.7 \pm 590.13$ & $1351.3 \pm 506.69$ & 0,643 \\
\hline Total proteins [g] & $56.5 \pm 25.26$ & $56 \pm 23.48$ & $56.8 \pm 26.32$ & 0,849 \\
\hline Fats [g] & $47.2 \pm 25.06$ & $45.7 \pm 25.55$ & $48 \pm 24.91$ & 0,625 \\
\hline $\begin{array}{l}\text { Total saturated fatty } \\
\text { acids[g] }\end{array}$ & $17.1 \pm 9.56$ & $16.7 \pm 9.84$ & $17.2 \pm 9.47$ & 0,779 \\
\hline $\begin{array}{l}\text { Total monounsaturated } \\
\text { fatty acids[g] }\end{array}$ & $18.9 \pm 11.22$ & $18.4 \pm 11.81$ & $19.1 \pm 10.94$ & 0,713 \\
\hline $\begin{array}{l}\text { Total polyunsaturated } \\
\text { fatty acids[g] }\end{array}$ & $6.8 \pm 4.3$ & $6.1 \pm 3.21$ & $7.1 \pm 4.78$ & 0,216 \\
\hline Total carbohydrates [g] & $194.4 \pm 8149$ & $205.8 \pm 90.14$ & $188.2 \pm 76.19$ & 0,245 \\
\hline Sacharose [g] & $41.8 \pm 31.14$ & $33.8 \pm 24.21$ & $46.2 \pm 33.68$ & 0,031 \\
\hline Laktose [g] & $8.6 \pm 8.79$ & $9.8 \pm 9.59$ & $7.9 \pm 8.31$ & 0,252 \\
\hline Starch [g] & $104.2 \pm 56$ & $121.7 \pm 64.99$ & $94.5 \pm 48.17$ & 0,008 \\
\hline Proteins/energy [kcal] & $229.1 \pm 102.75$ & $226.8 \pm 95.42$ & $230.3 \pm 107.11$ & 0,851 \\
\hline Fats/energy [kcal] & $417.4 \pm 221.77$ & $403.8 \pm 225.74$ & $424.9 \pm 220.6$ & 0,611 \\
\hline $\begin{array}{l}\text { Carbohydrates/energy } \\
\text { [kcal] }\end{array}$ & $721 \pm 307.98$ & $766.9 \pm 341.13$ & $695.9 \pm 287.27$ & 0,215 \\
\hline & & & & \\
\hline
\end{tabular}

Persons with $\mathrm{BMI} \geq 25 \mathrm{~kg} / \mathrm{m}^{2}$ more frequently than persons with $\mathrm{BMI}<25 \mathrm{~kg} / \mathrm{m}^{2}$ consumed sweet products other than gelatins and sweet bread. Among sweet products for persons with $\mathrm{BMI}>25 \mathrm{~kg} / \mathrm{m}^{2}$ sugar was on the first position (consumed 4-6 times a week), next were chocolates and cakes (consumed 2-3 times a week). Sweet drinks were also drunk more often by respondents with overweight and obesity.

Table 4. Characteristics of consumption frequency for chosen products that are sources of added sugar vs. BMI value

\begin{tabular}{lcccc}
\hline Products & $\begin{array}{c}\text { BMI Total } \\
\mathrm{kg} / \mathrm{m}^{2}\end{array}$ & $\begin{array}{c}\mathrm{BMl} \leq 25 \\
\mathrm{~kg} / \mathrm{m}^{2}\end{array}$ & $\begin{array}{c}\mathrm{BMl}>25 \\
\mathrm{~kg} / \mathrm{m}^{2}\end{array}$ & $\mathrm{p}$ \\
\hline Sugar & $5.4 \pm 2.05$ & $3.7 \pm 2.18$ & $6.4 \pm 1.18$ & $<0.001$ \\
\hline Bon bons, honey & $4.1 \pm 2.05$ & $3.1 \pm 1.84$ & $4.6 \pm 1.98$ & $<0.001$ \\
\hline Ice-cream, pudding & $3.4 \pm 1.88$ & $2.7 \pm 1.54$ & $3.9 \pm 1.91$ & $<0.001$ \\
\hline $\begin{array}{l}\text { Chocolate sweets (chocolate bar, } \\
\text { chocolate bon bons) }\end{array}$ & $4.5 \pm 1.83$ & $3.1 \pm 1.53$ & $5.3 \pm 1.52$ & $<0.001$ \\
\hline Cakes, doughnuts & $4.2 \pm 1.79$ & $2.6 \pm 1.36$ & $5.1 \pm 1.31$ & $<0.001$ \\
\hline Crackers & $4.4 \pm 1.85$ & $2.9 \pm 1.65$ & $5.2 \pm 1.4$ & $<0.001$ \\
\hline Chocolate & $4.4 \pm 2.17$ & $2.4 \pm 1.55$ & $5.6 \pm 1.5$ & $<0.001$ \\
\hline Gelees & $2.3 \pm 1.72$ & $1.9 \pm 1.42$ & $2.5 \pm 1.84$ & 0.064 \\
\hline Sparkling sweet drinks & $3.2 \pm 2.28$ & $2.1 \pm 1.69$ & $3.7 \pm 2.38$ & $<0.001$ \\
\hline Non-sparkling sweet drinks & $3.7 \pm 2.41$ & $1.8 \pm 1.6$ & $4.8 \pm 2.13$ & $<0.001$ \\
\hline Cornflakes & $2.7 \pm 6.39$ & $4.1 \pm 10.42$ & $1.9 \pm 1.66$ & 0.041 \\
\hline Cereals & $2.4 \pm 1.83$ & $2.3 \pm 1.83$ & $2.4 \pm 1.84$ & 0.637 \\
\hline Cereals with honey, hot chocolate & $1.3 \pm 0.99$ & $1.3 \pm 1.14$ & $1.2 \pm 0.91$ & 0.928 \\
\hline Musli & $1.3 \pm 1.05$ & $1.6 \pm 1.42$ & $1.2 \pm 0.74$ & 0.072 \\
\hline Sweet bread & $2.8 \pm 1.87$ & $2.9 \pm 1.96$ & $2.8 \pm 1.83$ & 0.812 \\
\hline & & & &
\end{tabular}

Adjusted to daily consumption of other hydrocarbons, fats and gender $s$ ratio calculated for unit $=5 \mathrm{~g}$ was 1.14 for both being overweight or obese. This means that one additional spoonful of sugar consumed daily increases the probability of having these disorders by about $14 \%$. From other analysed 
Table 5. Association between selected nutrients intake and risk of overweight and obesity (uni- and multivariate models)

\begin{tabular}{lcccccc}
\hline Variables & \multicolumn{3}{c}{ Univariate } & \multicolumn{3}{c}{ Multivariate* } \\
\hline & OR & $95 \% \mathrm{Cl}$ & $\mathrm{p}$ & $\mathrm{OR}$ & $95 \% \mathrm{Cl}$ & $\mathrm{p}$ \\
\hline Sucrose $(5 \mathrm{~g})$ & 1.08 & $1.01-1.17$ & 0,034 & 1.14 & $1.04-1.25$ & 0006 \\
\hline Lactose $(5 \mathrm{~g})$ & 0.89 & $0.72-1.09$ & 0,252 & & &, \\
\hline Starch $(5 \mathrm{~g})$ & 0.96 & $0.92-0.99$ & 0,014 & 0.92 & $0.88-0.97$ & 0,001 \\
\hline
\end{tabular}

*additionally standardized to fats, other hydrocarbons and gender

nutrients, starch intake was inversely associated with obesity and overweight $(\mathrm{OR}=0.92,95 \% \mathrm{CI}$ : $0.88-0.97$ for every $5 \mathrm{~g}$ of starch per day).

Analysis of the consumption frequency of products rich in sugar and fats showed that only sucrose-rich food items were associated with higher risk of overweight and obesity. Consumption level of 'cakes' was highly correlated with chocolate consumption $(\mathrm{r}=0,654 ; \mathrm{p}<0,0001)$, which is why two multivariate models were built. In univariate analysis, increased consumption of almost all sucrose-rich products was associated with an increase of overweight/obesity risk. However, in multivariate analysis, the most significant was level of sugar consumption (increase in consumption by 1 rank was associated with an over $60 \%$ higher risk of being obese/overweight), 'cakes', 'crackers', chocolate and sweet drinks (an increase of risk about 100\% in the case of 'cakes', over $80 \%$ in the case of 'crackers' and chocolate, and about $65 \%$ in the case of sweet drinks by 1 rank increase). More frequent muesli consumption was associated with a decrease in overweight/obesity risk (increased consumption by 1 rank was associated with lower risk - 57\%). No association was observed between the risk of obesity/overweight and fat-rich products.

\section{DISCUSSION}

Life style has a crucial influence on the development of overweight and obesity: improper nutrition (mainly increased consumption of food items rich in calories, fatty products and items containing sucrose) and low level of physical activity. In recent years, much has beebn said about added sugars (white and brown sugar, corn syrup, maple syrup, high fructose corn syrup, molasses, dextrose or honey) in the context of obesity, diabetes development and increased risk of cardiovascular diseases $[10,14]$. According to the guidelines of the National Food and Nutrition Institute in Warsaw, energy absorbed from added sugars should not exceed $10 \%$ of total energy intake. Unfortunately, the average amount of added sugars is increasing. According to American studies (NHANES) sweet carbonated drinks and energy drinks are the main source $-35.7 \%$. Cereal desserts constitute $12.9 \%$ of total added sugars, fruit drinks about $10.5 \%$, sweets $-6.1 \%$, sugar and honey $-3.5 \%$ [15]. In Poland, the sucrose intake per person has increased from $21 \mathrm{~kg}$ in 1950 to $39.7 \mathrm{~kg}$ in 2007 [16]. A correlation was found between the intake of added sugars (from sweet drinks) and diabetes, overweight, obesity, hypertension and metabolic syndrome, and described many times in publications $[17,18,19]$.

In the studied population, overweight was found among $33.8 \%$ of women and $50 \%$ of men, and obesity among $27.7 \%$ of women and $17.7 \%$ of men.

Even though the studied group included patients with cardiovascular disease who were under the supervision of clinic dieticians, the participants were still making basic nutrition errors, e.g. intake of simple sugars over $10 \%$ of total energy intake. The presented findings indicate a statistically significant correlation between BMI and sucrose intake: participants with overweight and obesity consumed $46.2 \mathrm{~g}$ of sucrose per day, while those with BMI lower than $25 \mathrm{~kg} /$ $\mathrm{m}^{2}$ consumed only $16.4 \mathrm{~g}$ of sucrose per day. These results are similar to those published by Brisbois [20], who estimated

Table 6. Association between consumption frequency of selected products rich in sugar and risk of overweight and obesity (multivariate models)

\begin{tabular}{|c|c|c|c|c|c|c|c|c|c|}
\hline \multirow[t]{2}{*}{ Variables } & \multicolumn{3}{|c|}{ Univariate } & \multicolumn{3}{|c|}{$\begin{array}{c}\text { Multivariate* } 1 \\
\text { McFadden's R2=0,698; } \\
\text { BIC }=83,826 ; \\
\text { correctly classified } 91.3 \%\end{array}$} & \multicolumn{3}{|c|}{$\begin{array}{c}\text { Multivariate*2 } \\
\text { McFadden's R2=0,714; } \\
\text { BIC }=81,206 ; \\
\text { Correctlyclassified } 93.7 \%\end{array}$} \\
\hline & $O R$ & $95 \% \mathrm{Cl}$ & $p$ & OR & $95 \% \mathrm{Cl}$ & $p$ & OR & $95 \% \mathrm{Cl}$ & $p$ \\
\hline Sugar & 2,31 & $1.72-3.10$ & $<0,001$ & 1.90 & $1.27-2.86$ & 0,002 & 1.62 & $1.05-2.51$ & 0,029 \\
\hline Bon bons/honey & 1.46 & $1.20-1.78$ & $<0,001$ & & & & & & \\
\hline Ice-cream / pudding & 1.46 & $1.17-1.83$ & 0,001 & & & & & & \\
\hline Chocolate products & 2.26 & $1.67-3.04$ & $<0,001$ & & & & & & \\
\hline Cakes & 3.82 & $2.39-6.10$ & $<0,001$ & 2.00 & $1.22-3.29$ & 0,006 & & & \\
\hline Crackers & 2.45 & $1.78-3.37$ & $<0,001$ & 1.84 & $1.15-2.94$ & 0,011 & 1.88 & $1.15-3.07$ & 0,011 \\
\hline Chocolate & 2.93 & $2.06-4.15$ & $<0,001$ & & & & 1.84 & $1.23-2.75$ & 0,003 \\
\hline Gelatins & 1.26 & $1.00-1.60$ & 0,050 & & & & & & \\
\hline Sweet non- sparking drinks & 1.97 & $1.56-2.50$ & $<0,001$ & 1.68 & $1.15-2.44$ & 0,007 & 1.64 & $1.13-2.40$ & 0,010 \\
\hline Cornflakes & 0.83 & $0.68-1.00$ & 0,052 & & & & & & \\
\hline $\begin{array}{l}\text { Cereals with honey and hot } \\
\text { chocolate, }\end{array}$ & 0.96 & $0.67-1.40$ & 0,807 & & & & & & \\
\hline Musli & 0.70 & $0.49-1.01$ & 0,055 & 0.43 & $0.23-0.81$ & 0,008 & 0.43 & $0.22-0.86$ & 0,016 \\
\hline Sweet bread & 0.98 & $0.80-1.19$ & 0,803 & & & & & & \\
\hline
\end{tabular}

*additionally standardized to gender 
added sugars intake among Canadian adults at an average of $52 \mathrm{~g}$ per day. Comparable trends were observed in Australia [21], but studies among the American adult population indicate an even higher intake, reaching $77 \mathrm{~g}$ per day [22].

Increased risk of obesity caused by increased consumption of simple sugars can be observed in all age groups. Mailk et al. [18] described the correlation between the intake of sweet drinks and increased risk of overweight among both children and adults. The results of NAHES III studies indicate the same relationship: people with higher BMI were drinking more sweet drinks compared to those with normal BMI [23]. Randomized PREMIER trials [24], carried out in a group of adults showed that a $335 \mathrm{ml}$ daily decrease in the intake of sweet drinks was connected with reduction in body mass by about $0.49 \mathrm{~kg}$ after 6 months observation.

Schluze et al. [25], assessed the relationship between consumption of sugar-sweetened beverages, weight, and risk of type 2 diabetes amid adult women and found that women with a higher intake of sweet drinks had a higher intake of total energy and lower intake of proteins, magnesium and cereal fibre. As can be expected, these correlated with greater weight gain and increased risk of development of type 2 diabetes. It should be pointed out that there are also some publications in which the authors did not find any connection between glycaemic index and BMI [26].

Studies by Miller et al. [27], carried among a population from central Indiana, USA, suggested that obesity and body fat are correlated with diet composition (dietary fat and sugar) rather than excessive energy intake. Similar results were found in the current study where the low energy value of the diet of elderly people (satisfying only $70 \%$ of their energy needs) and a too high intake of simple sugars and saturated fats are described. The nutrition errors had an impact on the development of overweight and obesity among $67.7 \%$ of men and $51.5 \%$ of women. On the other hand, there are some studies that do come to the same conclusion $[28,29]$. In a recent study by West and de Loy [28], focusing on 68 obese adults receiving fat (33\% of energy) in an energy restricted low-sucrose diet (5\% of energy), or an energy restricted sucrose-containing diet (10\% of energy), after 8 weeks, the body weight dropped in both groups, but difference between them was not statistically significant.

In another study, by Surwit at al. [29], 42 obese women followed an energy restricted low-fat diet (10\% of energy from fats, $19 \%$ from protein, $71 \%$ from carbohydrates). These diets were different in terms of carbohydrates content: one diet with $43 \%$ of energy from sucrose and another with $4 \%$ of energy form sucrose. After 6 weeks, body weight decreased: by $7 \mathrm{~kg}$ in the sugar-rich diet and by $7.4 \mathrm{~kg}$ in the low-sugar diet. Both studies illustrate that weight loss is a consequence of energy deficit.

The conclusions of some publications postulate that replacing sweet products by low energy sweeteners whatwill reduce the energy value of the diet, and reduce body mass [30]. In some countries (Australia, UK), a trend of lower consumption of added sugars has been observed, but the obesity problem has still increased in recent years [20,31]. Anderson et al. [32], analyzing the nutritional habits and 10year survival of elderly people (70-79 years), concluded that for persons consuming sweets and desserts the risk of death was higher than in the group of people consuming healthy products (vegetables, fruit, chicken, fish, milk products and cereals). It should be stated that in the group of individuals consuming sweets and desserts, the consumption of calories, fats and fatty acids was significantly higher: calories $(2,076$ vs. 1,703$)$ fats (36.1 vs. 27.5) and saturated fatty acids (10.0 vs. 7.5). The authors conclude that proper nutrition lengthens the life span.

A diet rich in sugar leads to many nutritional disorders (deficiencies in vitamins and minerals) that may be followed by the development of diet-dependent diseases [14]. Too high sugar consumption affects the lipid profile which may lead to the development of diseases of the cardiovascular system.

In an NAHES study estimating the influence of sugar on the risk of frequency of cardiovascular problems, it was shown that high sugar consumption, in amounts bigger that $\geq 30 \%$ of energy in comparison to low consumption $(<10 \%)$, correlated positively with a medium HDL cholesterol concentration, being on the level of $1.28 \mathrm{mmol} / \mathrm{l}$ vs. $1.40 \mathrm{mmol} / \mathrm{l}(\mathrm{p}<0.001)$.

A positive correlation was found in the case of changes in triglycerides concentration $(0.89 \mathrm{mmol} / \mathrm{l}$ vs. $0.81 \mathrm{mmol} / \mathrm{l})$ and LDL cholesterol concentration $(2.44 \mathrm{mmol} / \mathrm{l} \mathrm{vs} .2 .24 \mathrm{mmol} / \mathrm{l})$ [33]. In the Framingam Heart Study [34], a high level of triglycerides was described among persons consuming sweet drinks every day (about 25\% more often), compared to those who did not drink sweet beverages.

Similarly, in the Nurse's Health Study, the relationship between sweet drinks consumption and ischemic heart disease was proved. In a 24 -year observation study the risk of ischemic heart disease occurrence was higher by about $35 \%$ in a group of individuals drinking $\geq 2$ sweet drinks daily, compared with persons drinking $<1$ sweet drink monthly [35].

\section{CONCLUSIONS}

1. Individuals with overweight and obesity are in a group with higher risk of cardiovascular diseases. Simultaneously, improper nutrition patterns among overweight and obese people lead to the aggravation of already existing disorders. Consequently, in the examined group of elderly people with recognized cardiovascular problems, about $60 \%$ were overweight or obese.

2. The presented study allows the conclusion that too high an intake of simple sugars had the most clear impact on the development of overweight and obesity, and one additional spoonful (5 g) of sugar per day was correlated with an increase in the risk of obesity or overweight by about $14 \%$.

\section{REFERENCES}

1. Ludwig DS, Peterson KE, Gortmaker SL. Causes of obesity. Lancet 2001; 357: 1978-1979.

2. Obesity. Preventing and managing of the global epidemic. Report of a WHO consultation on obesity. WHO, Geneva 2000.

3. Biela U, Pajak A, Kaczmarczyk-Chałas K, Głuszek J, Tendera M. Frequency of overweight and obesity among women and men between 20-74 years old. Results of WOBASZ programme. Kardiol Pol. 2005; 63: 1-4 (in Polish).

4. Wykrzykowski B, Zdrojewski T. Overweight and obesity. NATPOL PLUS 2002 study. www.natpol.pl (asscessed on 25 April 2014)(in Polish).

5. Pająk A, Topór-Mądry R, Waskiewicz A. Body mass index and risk of death. POL-MONICA study in Polish population at middle-age. Kardiol Pol. 2005; 62: 101-105(in Polish).

6. Zatońska K, Janik-Koncewicz K, Ilow R, Regulska-Ilow B, Różańska D, Szuba A, et al. Prevalence of obesity - baseline assessment it the 
prospective cohortPONS study. Ann Agric Environ Med. 2011; 18(2): 246-250.

7. Ilow R, Regulska-Ilow B, Różańska D, Zatońska K, Dehghan M, Zhang $\mathrm{X}$, et al. Assessment of dietary intake in a sample of Polish populationbaseline assessment from the prospective cohort PONS study. Ann Agric Environ Med. 2011; 18(2): 229-234.

8. Yusuf S, Hawken S, Ounpuu S, Dans T, Avezum A, Lanas F, et al. Effect of potentially modifiable risk factors associated with myocardial infraction in 52 countries (INTERHEART study): case-control study. Lancet 2004; 364: 937-952.

9. Szponar L, Wolnicka K, Rychlik E. Album of food products and dishes. National Food and Nutrition Institute. Warsaw 2000 (in Polish).

10. Jarosz M. Polish nutritional guidelines - amendment. National Food and Nutrition Institute. Warsaw 2012 (in Polish).

11. Kłosiewicz-Latoszek L, Szostak WB, Podolec P. Nutrition Guidelines of Polish Forum of Circulation System Disease Prophylaxis. www.pfp. edu.pl (asscessed on 30 April 2014) (in Polish).

12. European guidelines in prophylaxis of cardiovascular diseases in clinical practice. Kardiol Pol. 2012; 70: 39-43 (in Polish).

13. European Ford Safety Authority (EFSA). Scientyfic Opinion on Dietary Reference Values for fats including Saturated fatty acids, polyunsaturated fatty acids, monounsaturates fatty acids and cholesterol. EFSA Journal 2010; 8: 1461.

14. Kłosiewicz-Latoszek L, Cybulska B. Sugar and health of obesity, diabetes mellitus and cardiovascular diseases. Probl Hig Epidemiol. 2011; 92: 181-186 (in Polish).

15. Van Horn L, Johnson RK, Fickinger BD. Translation and implementation of added sugars consumption recommendations: a conference Report from American Heart association. Circulation 2010; 122: 2470-2490.

16. Sekuła W, Figurska K, Barysz A, Ołtarzewska M. Results of nutrition monitoring among people in Poland. Żyw Człow Metab. 2008; 35: 371-395 (in Polish).

17. Malik VS, Popkin BM, Bray GA. Sugar-sweetened beverages, obesity, type 2 diabetes mellitus and cardiovascular disease risk. Circulation 2010; 121: 1356-1364.

18. Malik VS, Schulze MB, Hu FB. Intake of sugar-sweetened beverages and weight gain: a systematic review. Am J Clin Nutr. 2006; 84: 274-288.

19. Wojtyła-Buciora P, Stawińska-Witoszyńska B, Klimberg A, Wojtyła A, Goździewska M, Wojtyła K et al. Nutrition-related health behaviours and prevalence of overweight and obesity amongPolish children and adolescents. Ann Agric Environ Med. 2013; 20(2): 332-340.
20. Brisbois TD, Marsden SL, Anderson GH, Sievenpiper JL. Estimated intakes and sources of total and added sugars in the Canadian diet. Nutrients 2014; 6: 1899-1912.

21. Cobiac L. Sugars in the Australian diet: results from the 1995 National Nutrition Survey. Nutr. Diet. 2003; 60: 152-173.

22. Ervin, RB, Ogden CL. Consumption of added sugar among US adults, 2005-2010. NCHS data Brief 2013; 122: 1-8.

23. Troiano RP, Briefel RP, Carrol MD. Energy and fat intakes of children and adolescents in the United States: Data from the National health and Nutrition Examination Surveys. Am J Clin Nutr. 2000; 72: 1343-1353.

24. Chen L, Appel LJ, Loria C. Reduction in consumption of sugarsweetened beverages is associated with weight loss: the PREMIER trial. Am J Nutr. 2009; 89: 1299-1306.

25. Schulze MB, Manson JE, Ludwig DS, Coldiz GA, Stampfer MJ, Willet WC, et al. Sugar-sweetened beveragrs, weight gain and incidence of type 2 diabetes in young and middle aged women. JAMA 2004; 292: 927-934.

26. Rajeshwari R, Yang SJ. Secular trends in children's sweetened beverage consumption: the Bogalusa Heart Study. J Am Diet Assoc. 2005; 105: 208-214.

27. Miller WC, Lindeman AK, Niederpruem M. Diet composition, energy intake and exercise in relation to body fat in men and women. Am J Clin Nutr. 1990; 52: 426-430.

28. West JA, de Looy AE. Weight loss in overweight subjects following low-sucrose diet during diets. Int J Obes. 2001; 8: 1122-1128.

29. Surwit RS, Fenigols MN, McCaskill CC, Clay SL, Babyak MA, Brownlow BS, et al. Metabolic and behavioral effects of a higt-sucrose diet during weight loss. Am J Clin Nutr. 1997; 65: 1122-1128.

30. Vermunt SHF, Pasman WJ, Schaafsma G, Kardinaal AFM. Effects of sugar intake on body weight: a review. Obesity Revies 2003; 4: 91-99.

31. Barclay AW, Brand-Miller J. The Australian paradox: A substantial decline in sugars intake over the same timeframe that overweight and obesity have increased. Nutrients 2011; 3: 491-504.

32. Anderson AL, Harris TB, Tylavsky FA. Dietary patterns and survival of older adults. J Am Diet Assoc. 2011; 111: 84-91.

33. Welsh JA, Sharma A, Cunningham SA, Vos MB. Consumption of added sugars and indicators of cardiovascular disease risk among US adolescents. Circulation 2011; 123: 249-257.

34. Dhingra R, Sullivan L, Jacques PF. Soft drink consumption and risk of developing cardiometabolic risk factors and the metabolic syndrome in middle-aged adults in community. Circulation 2007; 116: 480-488.

35. Fung TT, Malik V, Rexrode KM. Sweetened beverage consumption and risk coronary heart disease in women. Am J Clin Nutr. 2009; 89: 1037-1042. 